\title{
PEDAGOGIAS MEMÉTICAS EM TEMPOS DE PANDEMIA
}

\author{
MEMÉTIC PEDAGOGY IN PANDEMIC TIMES
}

\section{PEDAGOGÍAS MEMÉTICAS EN TIEMPOS DE PANDEMIA}

\author{
Kaio Eduardo de Jesus Oliveira ${ }^{1}$
}

\section{RESUMO}

Os memes na cultura digital materializam a função pedagógica da comicidade e do humor em nosso tempo. Isso ajuda a explicar como a propagação dos mais variados tipos de memes replicados a partir de temáticas inerentes ao cenário pandêmico provocado pela viralização do Novo Corona vírus em 2020 produziram sentidos e subjetividades. Os memes incorporam a construção discursiva deste cenário, conectando-nos em nossos isolamentos, reforçando questões indentitárias, produzindo pedagogias e situações de aprendizagem. Não, obstante enquanto dispositivos comunicacionais da cultura digital, a capacidade pedagógica dos memes, mesmo que limitada, em sua profundidade comunicativa, mostra-se inquestionável em termos de eficácia. Sendo assim, por meio de uma pesquisa qualitativa este artigo como objetivo geral analisar a atuação dos memes na comunicação e na formação da opinião publica na internet durante a pandemia de Covid-19.

PALAVRAS-CHAVE: Memes. Educação. Cibercultura.

\section{ABSTRACT}

Memes in digital culture materialize the pedagogical function of comedy and humor in our time. This helps to explain how the spread of the most varied types of memes replicated from themes inherent to the pandemic scenario caused by the viralization of the New Corona virus in 2020 produced meanings and subjectivities. Memes incorporate the discursive construction of this scenario, connecting us in our isolations, reinforcing indemnity issues, producing pedagogies and learning situations. No, despite being communicational devices of digital culture, the pedagogical capacity of memes, even if limited, in its depth, is unquestionable in terms of effectiveness. Therefore, through a qualitative research this article as a general objective to analyze the role of memes in communication and the formation of public opinion on the internet during the Covid-19 pandemic.

KEYWORDS: Memes. Education. Cyberculture.

\section{RESUMEN}

Os memes en la cultura digital materializan la función pedagógica de la comedia y el humor en nuestro tiempo. Esto ayuda a explicar cómo la difusión de los más variados tipos de memes replicados a partir de temas

Submetido em: 03/11/2020 - Aceito em: 03/01/2020 - Publicado em: 25/01/2021

1 Doutor em Educação (Universidade Tiradentes); Mestre em Educação (Unit). Professor da Faculdades Integradas de Sergipe (FISE). Pesquisador do Grupo de pesquisas em tecnologias da informação e Cibercultura- Getic. E-mail: kaioeduardojo@gmail.com 
inherentes al escenario pandémico provocado por la viralización del virus Nueva Corona en 2020 produjo significados y subjetividades. Los memes incorporan la construcción discursiva de este escenario, conectándonos en nuestros aislamientos, reforzando cuestiones de indemnización, produciendo pedagogías y situaciones de aprendizaje. No, a pesar de ser dispositivos comunicacionales de la cultura digital, la capacidad pedagógica de los memes, aunque limitada, en su profundidad, es incuestionable en términos de efectividad. Por ello, a través de una investigación cualitativa este artículo tiene como objetivo general analizar el papel de los memes en la comunicación y la formación de la opinión pública en internet durante la pandemia Covid-19.

PALABRAS CLAVE: Memes. Educacion. Cibercultura.

\section{INTRODUÇÃO}

Um fato muito comum quando se fala de memes, em muitas situações na cultura digital, é o recorrente uso do termo viralização implicado a popularização destes artefatos, quando na verdade os memes são difundidos por sua capacidade de replicação e não apenas por se tornarem uma viral, ou pela viralização. Não obstante, a diferenciação entre os conceitos de viral e memes, acabam confundindo muita gente.

Conceitos emprestados da biologia são muito comuns pra caracterizar a ambiência on-line deste fenômeno. O termo viral, por exemplo, pode ser empregado a um tipo de conteúdo que é propagado milhares de vezes na rede. Assim, como podemos nos referir a doenças como a gripe ou a Covid-19, que se espalham pela sociedade a partir da propagação de um vírus. Apesar de serem transmitidas para milhares de pessoas, elas continuam sendo a mesma doença. Já um meme, por sua vez, pode ser caracterizado pela variação ou recombinação de uma ideia original que é apropriada e passa por transformações constantes enquanto avança pelos ambientes da internet.

Neste contexto, enquanto um viral é implicado a um conteúdo que se torna popular por sua ampla capacidade de propagação, um meme pode ser caracterizado pela ampla capacidade de gerar autoria e recombinação que um conteúdo, temática ou ideia pode possibilitar e adquirir pela replicação e pelas variações que os usuários de ambientes on-line e mídias sociais podem produzir. 


\section{Revista Docência e Cibercultura}

Trata-se de um elemento que se dissemina via internet, mas que, apesar de preservar referências comuns, é frequentemente alterado para novos contextos e significados, associados à visão de mundo de cada autor. Um mesmo meme pode ser reconfigurado para transmitir uma ideia em situações opostas, adaptando-se o texto e, provavelmente, a composição dos personagens, bem como sua estética, que podem ser midiatizadas por diferentes intencionalidades.

Dessa forma, este tipo de linguagem digital integra o nosso arsenal diário de conexões com o mundo, por exercícios de representação e modos de dizer nas mídias sociais pela internet. Representa uma opção de transmissão de conteúdos em formato reduzido. Ao passo que a prática de leitura e apropriação de textos mais longos não é um hábito muito comum ao perfil de sujeitos da cultura digital, torna-se mais prático encaixar ao longo do cotidiano o consumo efêmero dos memes.

Diante disso, quando um vírus de rápida propagação e alta letalidade transforma a ordem mundial do planeta e promove um conjunto de mudanças que implicam em um "novo normal", caracterizado por medidas sanitárias de prevenção, isolamento social, uso continuo de mascaras, etc., os memes passaram a exercer um papel de protagonismo na disseminação de informações, mesmo que permeados pelo humor e pela comicidade da mensagem. Deste modo, é salutar entender como os memes enquanto artefatos da comunicação digital funcionam na formação da opinião publica por meio da internet.

Por meio da analise de memes veiculados na internet durante a pandemia de Covid-19 no ano de 2020, esta pesquisa qualitativa do tipo exploratória tem como objetivo analisar a atuação dos memes na comunicação e na formação da opinião publica na internet durante a pandemia de Covid-19. Vale destacar que os memes não se resumem ao formato em que são apresentados ou compartilhados em redes, em imagens, vídeos, sons, etc. Mas ao modo, como ideias, intencionalidades, subjetividades e autoria são replicadas em diferentes contextos. Entretanto, para efeito de comunicação, neste trabalho apresentamos como exemplificação, memes em formato de imagens, especialmente exemplos que foram amplamente difundidos no Brasil durante o primeiro semestre de 2020. 
Portanto, a seguir apresentamos uma discussão sobre o que são memes na cultura digital, como se caracterizam e qual seu papel enquanto gênero digital. Em seguida, evidenciamos como a produção de memes atuou na produção de sentidos e significados relacionados à saúde pública e sobre a Ciência durante a pandemia, produzindo o que chamamos neste trabalho de "pedagogias meméticas".

\section{O QUE SÃO MEMES?}

O conceito de meme, e sua controversa origem foi articulado pela primeira vez de forma despretensiosa, em um argumento proposto pelo renomado etólogo Richard Dawkins (1976) em seu livro O Gene egoísta, onde propunha um termo para explicar os processos de replicação e evolução cultural que lhe chamaram a atenção quando iniciou sua defesa à tese do determinismo genético.

Embora o termo seja o mesmo, na cultura digital, memes são geralmente apontados como conteúdos rasos e despretensiosos, como simples manifestações de piadas situacionais que repercutem um fato ou acontecimento em ambiência digital. Em outros contextos entende-se memes apenas como brincadeiras ácidas e maldosas, cujo objetivo é desestabilizar ou ofender alguém. No entanto, essas noções são frutos de uma compreensão equivocada sobre o fenômeno derivada de uma percepção que os entende como "cultura inútil" ou "besteirol". Deve-se em parte à ausência de estudos que se debrucem sobre o universo polissêmico dos memes, a partir dos usos e das apropriações dessas produções em contextos comunicacionais.

Pelo potencial discursivo, a polissemia materializada em um meme, pode ser entendida como a capacidade que este artefato tem de adquirir um novo sentido, ou promover variados significados. Deste modo, numa ação de interpretação de um meme, sempre atribuímos um sentido individual, ou ao associa-lo a nossa visão de mundo. Mas, ao compartilha-los em rede social, o disponibilizamos numa perspectiva de aprovação ou desaprovação ao seu conteúdo, que pode ou não ser ressignificado e seguir adiante. 
Podemos assim, entender os memes como construções culturais que se articulam e são difundidos por agentes humanos e grupos organizados na internet. Isto é, não há um poder "misterioso" dos memes em si, como supunha Blackmore (2000) em The meme Machine, que impulsiona os processos de difusão cultural, mas a articulação de redes de significados construídas pelas pessoas em torno deles, mediadas por dispositivos e artefatos.

Os memes na internet ganham repercussão pela velocidade de propagação e por sua capilaridade, ou seja, o modo como alcançam o público e os indivíduos que não buscam diretamente, por aquele conteúdo. Isso é possível graças às práticas de compartilhamentos e disseminação, em variadas mídias, como grupos de WhatsApp, mensagens de texto, áudios, vídeos, etc. O que o caracteriza como um fenômeno da cultura digital, posto que sua circulação não se limite apenas as rede sociais. Entretanto, é nas redes sociais que têm ganhado sentido e se popularizado de modo mais expressivo e materializado as experimentações coletivas dos sujeitos.

Um meme torna-se um fenômeno típico da internet ao passo que pode se apresentar como uma coleção de textos, imagens, comportamentos difundidos, desafios ou memórias compartilhadas. Não se resume a um padrão estético ou simplesmente a uma piada. É capaz de construir pontes e ao mesmo tempo reforçar debates ideológicos, questões culturais e sociais.

Diante dessa ambiência estética intencionalmente grotesca, a composição rústica e mal definida torna-se uma característica na gênese dos memes na cultura digital. Ironicamente, a falta de cuidado na produção se legitima como a estética própria do mundo on-line e passa a ser intencionalmente produzida de acordo com interesses diversos, incluindo campanhas políticas e publicitárias, voltadas a atingir um público mais jovem ou simplesmente a produção corriqueira cotidiana.

É possível perceber que as formas de humor, implicadas aos diferentes tipos de memes, são um elemento fundamental para a popularização deste tipo de conteúdo. Em uma análise do humor na internet, Shifman (2014) enfatiza que o humor das redes sociais pode recorrer, a alguns elementos bem específicos. Segundo a autora, ele baseia-se ou é estrelado, geralmente, 
por pessoas comuns; questiona ou ridiculariza o debate público; investe em uma comicidade de incongruência (quebras de expectativas); usa linguagem simples e popular; apresenta repetitividade; e dá ênfase às situações excêntricas ou fora do comum. Algumas dessas características podem ser relativizadas para os conteúdos científicos incorporados na produção de memes, no debate politico, social ou cultural.

Os formatos peculiares de experimentações de nossas ações na internet, comumente, nos chamam a atenção para disputas ou discussões públicas e sociais, questões de gênero, discursos sobre preconceito, política, entre outros assuntos que se tornam populares e são lançados à opinião pública por meio da comicidade do conteúdo produzido e compartilhado.

Portanto, memes construídos e replicados por meio da estética das imagens, são expressões particulares, comunicam intencionalidades, são testemunhas de mudanças ocorridas, indicam compreensão e visões de mundo, ou discordâncias, registram momentos que ficam na memória como álbuns, mas exibidos de modo efêmero. Eles podem circular pelos ambientes da internet contando e recontando histórias, provocando e estimulando a construção de narrativas do nosso cotidiano e podem alcançar públicos que potencialmente não eram o objetivo da interlocução.

Operando na lógica dos conteúdos abertos da internet, qualquer pessoa pode se apropriar de um meme que melhor represente ela mesma, seus humores, suas opiniões, suas subjetividades. Da mesma forma, numa reação em cadeia, se alguém da sua lista de contatos se identificar com um post, essa imagem seguirá sua jornada de compartilhamentos infinitos, a não ser que aquele conteúdo perca o sentido ou caia no limbo dos memes esquecidos. Isso explícita o modo como os memes ganham repercussão em rede, atrelados aos sentimentos e as subjetividades dos sujeitos.

Portanto, entender o modo como estes artefatos produzem situações de aprendizagem, reproduzem sentidos e produzem significados, é um exercício indispensável, ao passo que se tornam um dos principais modos de dizer e de se comunicar pela linguagem digital do nosso tempo. Deste modo, a seguir discutiremos como os memes produzem diferentes pedagogias 
na internet durante o cenário de pandemia, a partir de exemplos que ganharam notoriedade no debate público da internet em 2020.

\section{PEDAGOGIAS MEMÉTICAS NA PANDEMIA}

No Brasil, o grande sucesso das mídias sociais possibilita modos de interação cunhados na criação de perfis individuais e páginas autorais com moderação geralmente coletiva, para a produção de memes. Nelas, são inúmeros os casos de memes que possuem autoria reconhecida ou reconhecível, o que se torna uma dinâmica que diz muito sobre à produção destes conteúdos, que está desarticulada da necessidade de uma expertise profissional.

[...] os memes são conteúdos populares e amadores que em teoria podem ser feitos por qualquer usuário da rede. Mas não é isso que acontece na prática. Apesar de vermos memes por toda parte, a produção desse conteúdo está concentrada em apenas $22 \%$ dos internautas. Ou seja, a maior parte das pessoas acaba se identificando e refletindo o pensamento de um grupo seleto de criadores de memes. (CONSUMOTECA, 2019, On-line).

A partir de todas estas características, no ano de 2020, com a multiplicação dos casos de Covid-19 em contexto pandêmico, com alto grau de letalidade, foi acompanhada pelo crescente protagonismo das pessoas nas mídias e nas conversas informais pela rede. Nestes ambientes, como tem sido muito comum, os memes articularam um modo de comunicação peculiar, possibilitando a disseminação de informações e ampliando a repercussão do debate público em conteúdos reduzidos e com diferentes características.

Nesse mesmo cenário, a população dependente de esclarecimentos, orientações e atualizações constantes, tornou-se uma audiência amplificada, ao passo que cada acontecimento tornou-se um tema fecundo para a produção memética, sempre mediados pela "zoeira", pela critica social ou política. O protagonismo dos memes nas mídias sociais, decorrente do isolamento social tornou-se também o meio ideal para a replicação de memes que repercutiram e repercutem questões sobre a pandemia, sobre Saúde pública e Ciência. 


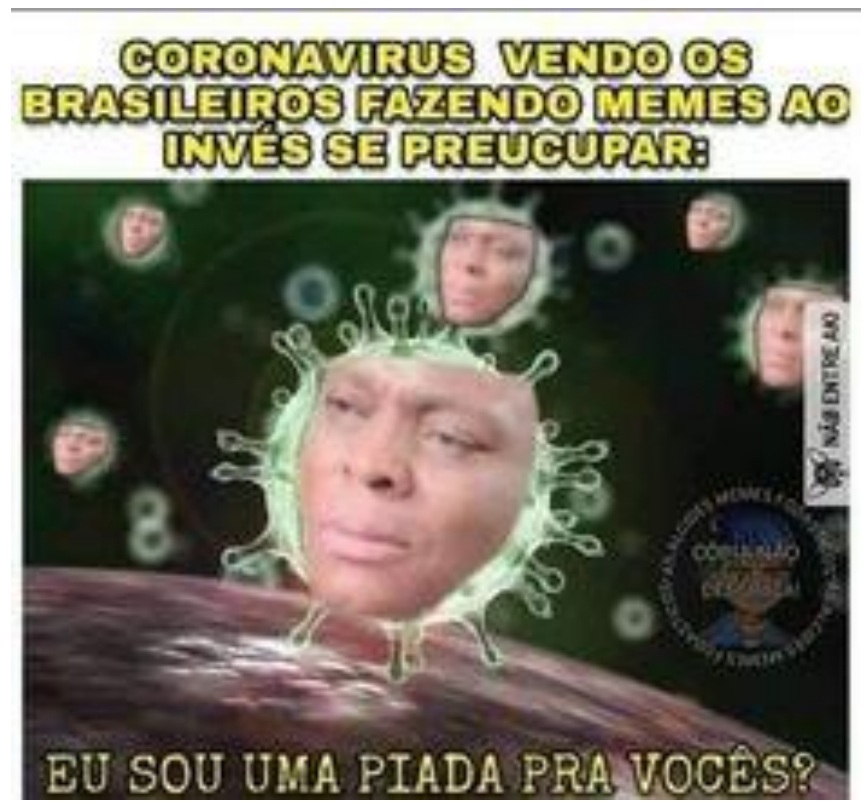

Figura 1: Corona vírus no Brasil

Fonte: http://portaljornaldonorte.com.br/brasileiros-compartilham-mais-memes-do-que-noticiassobre-o-coronavirus/. Acesso em: 27 out 2020.

Neste cenário de ampla produção e replicação de memes, aprendemos em muitos exemplos, com imagens, áudios, vídeos, entre outros formatos que o isolamento social é importante para conter a curva de disseminação do coronavírus. Conseguimos, ou tentamos explicar isso aos idosos, adaptando a mensagem do jornalismo e das autoridades de Saúde, aos formatos que eles respeitam e compreendem de uma maneira mais leve e bem humorada. 


\section{Revista Docência e Cibercultura}

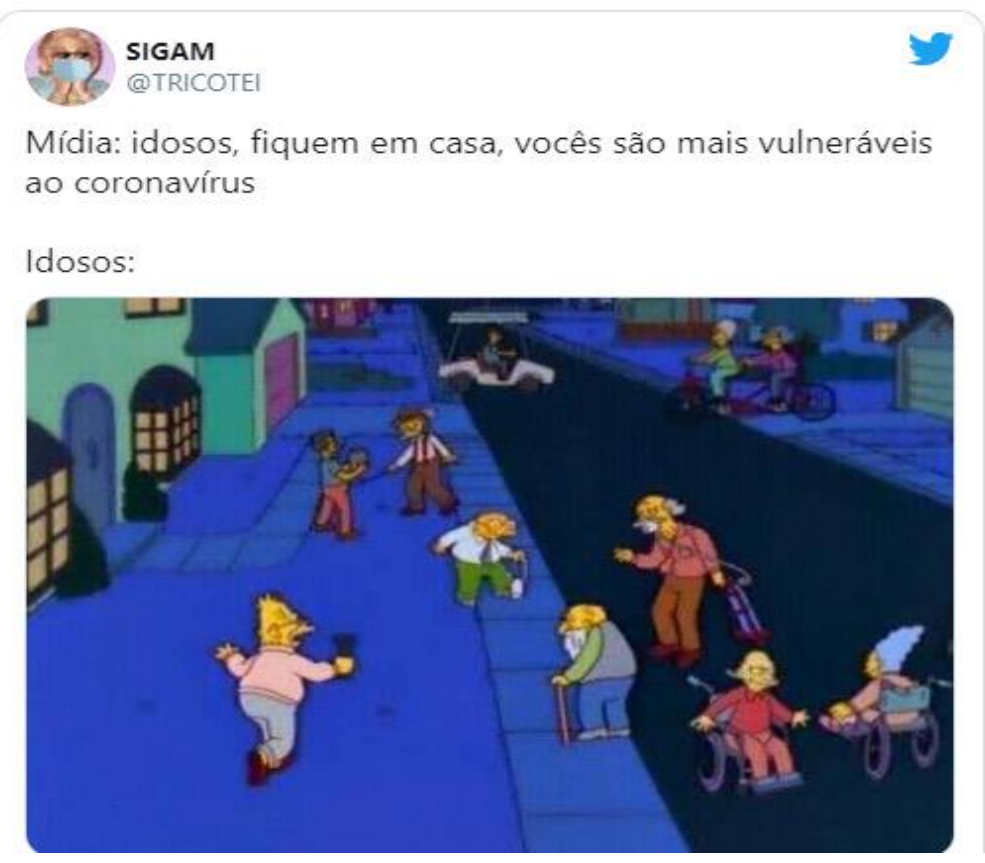

Figura 2: Idosos e grupo de risco

Fonte: https://www.uol.com.br/universa/noticias/redacao/2020/03/20/coronavirus-internet-quer-sabercomo-manter-idosos-em-casa-veja-memes.htm. Acesso em: 27 out. 2020.

Portanto, a capacidade pedagógica dos memes pode até ser limitada em seu formato, mas se mostrou inquestionável em termos de eficácia. Uma vez que para entender um meme sobre alguma questão relacionada à pandemia, não é preciso entender os termos técnicos da Ciência, da infectologia, etc. Basta observar as relações dialógicas que se estabelecem na construção dos sentidos de sua linguagem, posto que ele pode agregar diferentes formas de expressão, em um único artefato.

Os memes enquanto artefatos culturais podem parecer um singelo meio de entretenimento, que as pessoas fazem uso seja para alertar, ironizar ou até mesmo apavorar a população no cenário de pandemia. Não obstante, também carregam em suas significações modos de ironizar decisões de autoridades politicas, evidenciar o negacionismo da população quanto à atuação da Ciência, ou até mesmo mostrar sua relevância no combate ao coronavírus. 
Em um cenário onde a informação tornou-se cada vez mais necessária, o humor presente nos memes também flexibilizaram a comunicação, tornando-a mais leve, ao passo que produzem narrativas que passam a incorporar a discussão pública de um modo mais fluido, potencializado pela capacidade de autoria e auto-publicação de um sujeito que não necessariamente está envolvido nos meios de produção científica e na comunicação profissional, mas também ironizam o cenário político e social.

\section{PROTEJA VOCÊ \& OS OUTROS do Coronavirus}
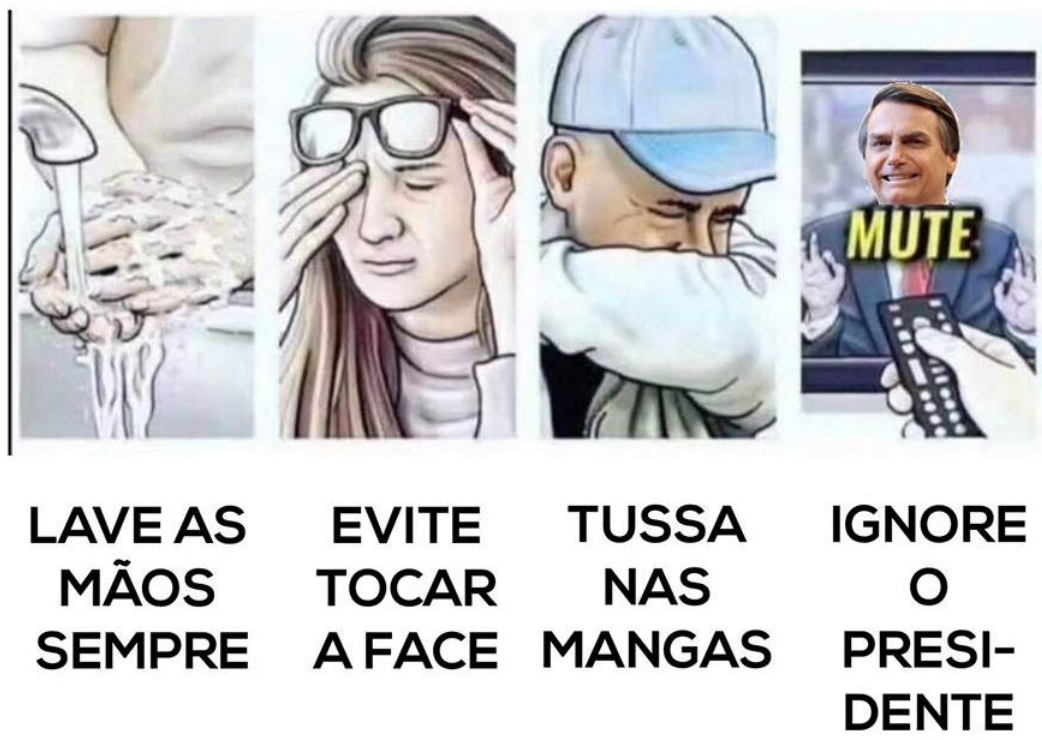

Figura 3: Medidas de proteção e critica politica

Fonte: https://www.museudememes.com.br/quando-o-viral-vira-meme-a-propagacao-do-coronavirusna-internet/. Acesso em: 27 out 2020.

O tom imprimido nos enunciados de muitos memes durante a pandemia tende para a ironia, para a carnavalização de um discurso oficial e não retira deles o lado crítico, pelo contrário, fortifica a criticidade: são como avaliações sociais que retratam acontecimentos sob um determinado ângulo (BAKHTIN, 2003, p. 195-196). As condições sociais, políticas, econômicas e culturais intervêm em nós, sujeitos enunciadores, influenciando nossas práticas 


\section{Revista Docência e Cibercultura}

discursivas. Não há como separar o sujeito enunciador do seu local de enunciação. Ao escolher replicar ou não um meme, o sujeito assume sua atitude ativamente responsiva e indicia sua posição social, histórica e ideológica diante do meme.

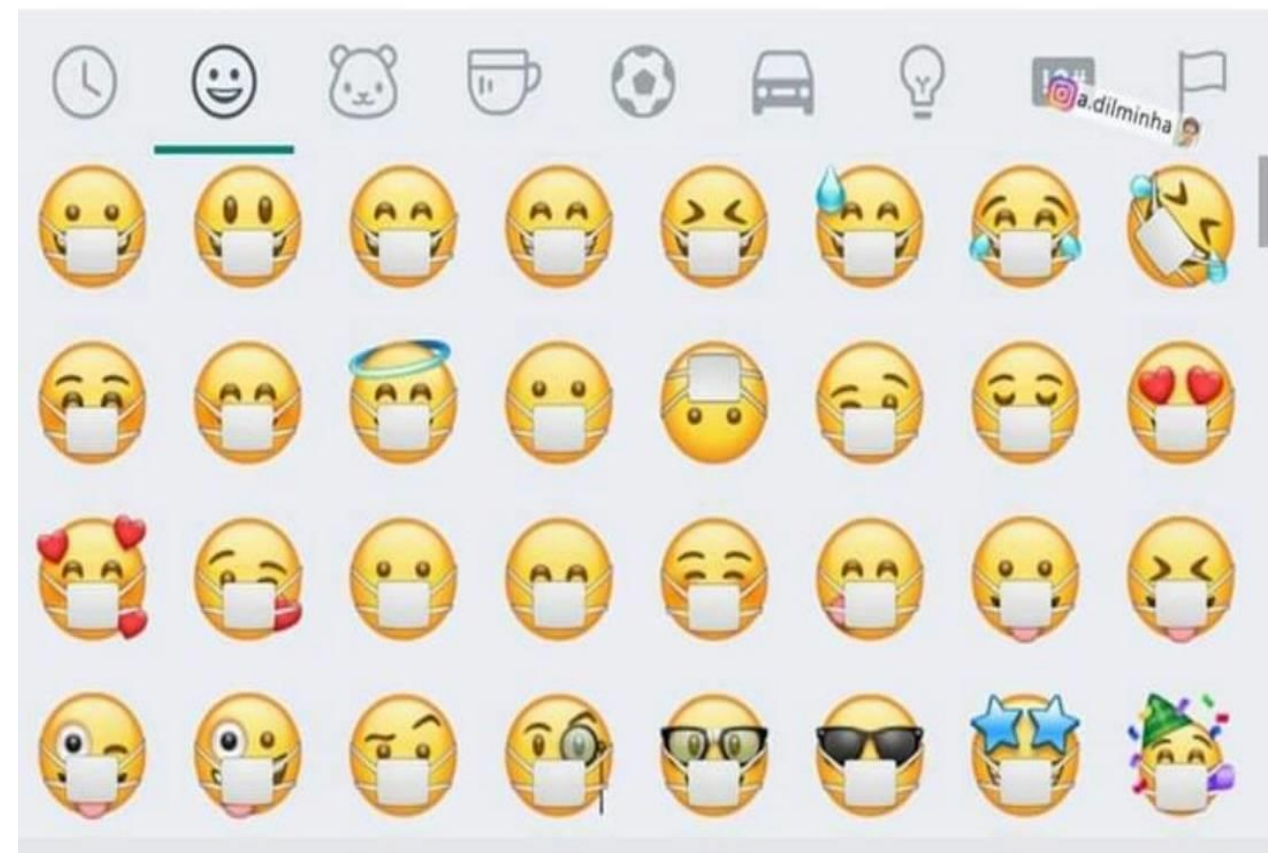

Figura 4: Use mascaras em emoji

Fonte: https://www.museudememes.com.br/quando-o-viral-vira-meme-a-propagacao-docoronavirus-na-internet/. Acesso: 27 ou 2020

Vale destacar que em alguns casos, os memes funcionam também como elementos de crítica e banalização da própria Ciência e do conhecimento científico, por esse formato de popularização de temas que repercutem pela polissemia humorística. Esse tipo de linguagem permeia temas que estão e que não estão no debate público dos usuários, o que promove a reprodução de pseudociências e outros conteúdos que replicam informações enganosas, mas que ganham popularidade devido ao apelo da piada e da brincadeira. 


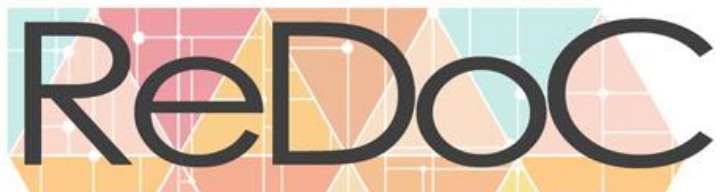

\section{Revista Docência e Cibercultura}

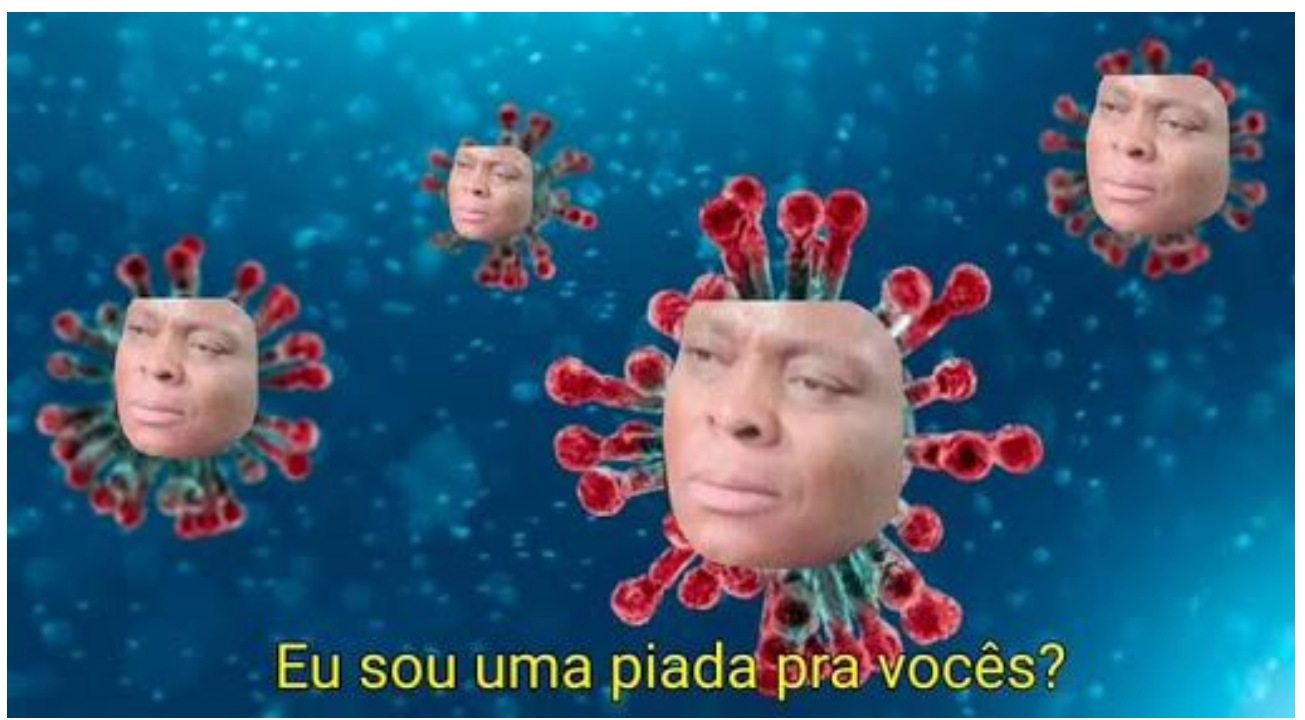

Figura 5: Memes, corona vírus e negação à ciência

Fonte: https://www.museudememes.com.br/quando-o-viral-vira-meme-a-propagacao-do-coronavirusna-internet/. Acesso em: 27 out. 2020

Neste mesmo deslocamento da linguagem produzido pelo meme, há também critica a pseudociências ou ao negacionismo, pela interface do humor e da brincadeira em rede, que faz com que um sujeito possa enxergar no debate um importante instrumental para uma possível construção de seus próprios sentidos na leitura e no compartilhamento. Instrumental este, que tende a se posicionar em diversos pontos, como social e educacional e, sobretudo, como forma de trazer indícios para compreensão da Ciência em um cenário onde informação e fatos científicos são indispensáveis.

Assim, durante a pandemia, além de produzirem pedagogias, situações de aprendizagem e disseminarem informação, os memes também funcionam como válvula de escape para as tensões do isolamento social, já que, além do teor didático em replicação social, os memes são feitos preferencialmente para te fazer rir (mesmo que da própria tragédia). Essa "capacidade de suavização" do humor na internet ajuda a lidar com o estresse e com a excitação em períodos de isolamento e de "inquietações digitais". 


\section{CONSIDERAÇÕES FINAIS}

Rir da nossa própria tragédia tem seu valor social, especialmente diante de uma pandemia. Os memes, enquanto modos de expressão do nosso cotidiano fazem parte dessa história, nos conectando socialmente, mesmo em nossos isolamentos, reforçando o nosso senso de comunidade, concedendo pequenos intervalos à ansiedade e pressionando os indivíduos mais resistentes a adotar as medidas de segurança necessárias para o momento, ou até mesmo difundindo informações através de diferentes tipos de humor.

\section{rindo de memes do corona / espirrei}

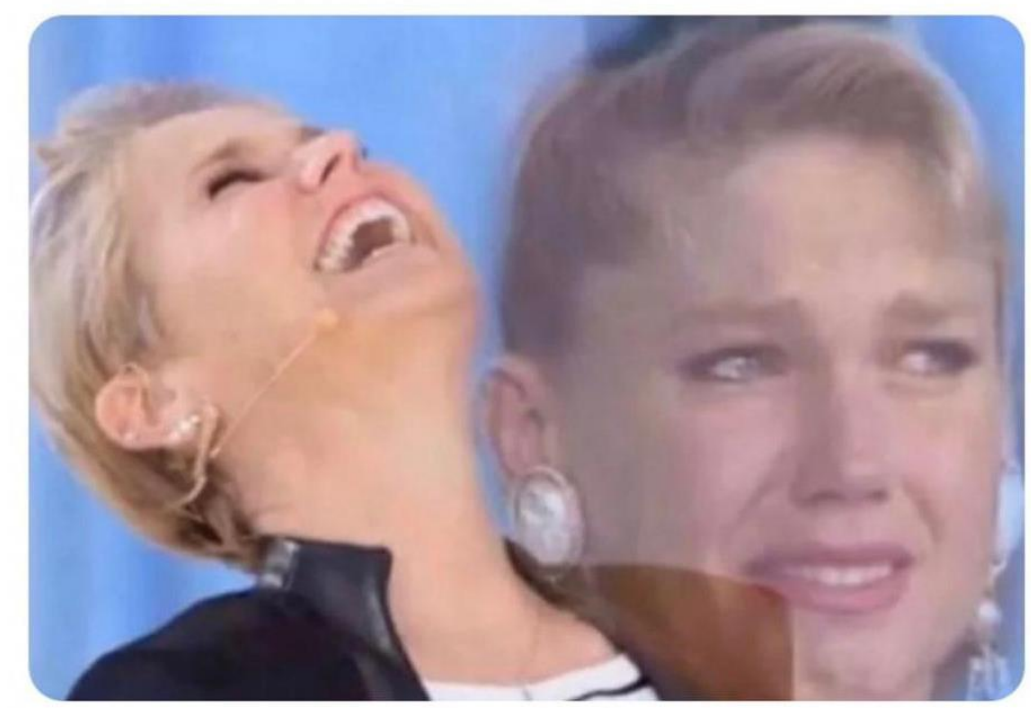

Figura 6: Memes, riso e Covid-19

Fonte: https://www.museudememes.com.br/quando-o-viral-vira-meme-a-propagacao-docoronavirus-na-internet/. Acesso: 27 out. 2020

Não é à toa que para compreender a comicidade de um meme durante a pandemia é preciso reintegrá-lo a seu contexto original e social. Atrelado a essa noção, Henri Bergson em O Riso (1983) esclarece que todo riso tem uma função social: deve responder a certas exigências da vida comum e deve ter um significado social. A função social também pode nascer de uma 


\section{Revista Docência e Cibercultura}

relação entre duas pessoas. É um humor negociado, ajustado, privado, que nasce por tentativa e erro e ajuda a unir quem dele se serve.

Além disso, Bergson (1983) chama atenção para a função pedagógica da comédia. Para o filósofo, o riso é um fenômeno social que serve para punir comportamentos desviantes e pressionar seus responsáveis a retomar os padrões socialmente aceitos. Em geral, os comportamentos desviantes risíveis contam com algum componente de rigidez que contraria a mobilidade natural da vida.

Portanto, a cultura digital articulada pela ubiquidade das tecnologias digitais em mediação com as potencialidades do vídeo, do áudio, das imagens em movimento, das hashtags e das campanhas de engajamento coletivo das redes, tem oportunizado acesso a informação e maior participação social no debate sobre alguns assuntos que compõem nosso cotidiano. Assim, os memes sobre o coronavírus ou sobre a Covid-19, produziram diferentes situações de aprendizagem sobre a pandemia, ao passo que replicaram discursos, medidas de proteção, ações de combate e prevenção, etc..

Evidenciamos que a replicação de memes neste contexto, possibilitou: informação a população sobre temas de Ciência; possibilitou a promoção do debate sobre os diversos aspectos que influenciam a Ciência no contexto de pandemia; fez com que o público não especializado tivesse uma visão crítica da Ciência (de acordo com seus modos de ler e interpretar); estimulou o combate as pseudociências, mostrando algumas respostas para as grandes questões em debate; Puderam mostrar os processos, os personagens e as controvérsias envolvidas na atividade científica; Promoveu uma aproximação entre ciência e sociedade especialmente pela popularização de medidas sanitárias de prevenção a Covid-19.

Portanto, quando a imaginação e a criatividade consegue transferir questões sobre a pandemia para o âmbito da memesfera, a ameaça é anulada e torna-se risível. Mesmo que momentaneamente. Deste modo, o humor e o riso materializados em um meme, tornaram-se mais que um elemento da comunicação, tiveram o poder de aliviar as tensões de um cenário nunca antes narrado na historia da internet, mesmo que por alguns segundos. 
Concluímos com este texto, que produzir informação e conhecimento passa a ser, portanto, uma condição para transformar ordem social vigente no contexto da cultura digital. Devido a este formato efêmero de comunicação, isso pode ser realizada de forma descentralizada e de maneira não formatada ou preconcebida, com a finalidade de ocupar os espaços, através das redes, com abordagens inesperadas. Com isso, a apropriação da cultura digital passa a ser fundamental na lógica memética. Em razão que, ela já indica, intrinsecamente, um processo crescente de reorganização das relações sociais mediadas pelas tecnologias digitais que podem afetar em maior ou menor escala, todos os aspectos entre cidades e ciberespaços e sujeitos.

\section{REFERÊNCIAS}

BAKHTIN, Mikhail. Problemas da Poética de Dostoievski. Tradução Paulo Bezerra. Rio de Janeiro: Forense-Universitária, 2013.

BERGSON, H. O riso: ensaio sobre a significação do cômico. Tradução: Nathanael C. Caixeiro. Ed. Zahar: Rio de Janeiro, 1983.

BLACKMORE, S. The meme machine. Oxford: Oxford University Press, 2000.

CHAGAS, V. A cultura dos memes: aspectos sociológicos e dimensões politicas de um fenômeno do mundo digital. (Org). Salvador: Edufba, 2020.

CONSUMOTECA. In meme we trust. Disponível em: <gente.globosat.com.br/in-meme-wetrust>. Acesso em: 8 out. 2019.

DAWKINS, R. O gene egoísta. Belo Horizonte: Ed. Itatiaia, 2001.

OLIVEIRA, K. E. J. A ciência dos memes e os memes da ciência: educação e divulgação científica na Cultura digital (Tese de Doutorado em Educação). Universidade Tiradentes: Aracaju, 2020.

SHIFMAN, L. Memes in digital culture. Massachusetts, MA: MIT Press, 2014.

Este é um artigo de acesso aberto distribuído sob os termos da Licença Creative Commons Atribuição Não Comercial-Compartilha Igual (CC BYNC- 4.0), que permite uso, distribuição e reprodução para fins não comerciais, com a citação dos autores e da fonte original e sob a mesma licença. 